\title{
ISSUES OF CONSERVATION AND ADAPTATION IN PROTECTING KASHMIR'S VERNACULR HERITAGE
}

\author{
M. Saleem Beg*
}

\begin{abstract}
The vernacular architecture of Kashmir represents a traditional knowledge base that has evolved in response to the climatic conditions, the traditional lifestyle of the residents, and various natural threats in the form of earthquake, flood etc., affecting the region. Yet, the advance into the "modern scientific age" has witnessed an eroding of this rich heritage. The paper examines the salient features of Kashmir's vernacular architecture, the challenges it faces and the steps that have been taken to protect it, including how to adapt it to contemporary life.
\end{abstract}

Keywords: Kashmir, Vernacular Architecture, Heritage, INTACH Jammu and Kashmir, Conservation.

\section{INTRODUCTION}

It is more than ten years since Kashmir witnessed one of the most severe earthquakes since independence in 1947. The earthquake of 2005 was followed by a series of studies, based on examination of the devastation that took place in the northern mountainous regions of the valley, to understand the pattern of destruction and damage that occurred (Figure
1). The unprecedented floods of 2015 with widespread damage of the built fabric again raised the issue of not only how and where should construction happen, but also more importantly what type of construction should take place.

The built fabric of Kashmir Valley has always been susceptible to the threat of disasters like fire, earthquake and floods. Vernacular accounts record a series of floods and earthquakes that devastated the region, down the centuries (Shah, 2002). Yet local builders, the masons and carpenters of yesterday maintained a unique system of construction which took into account both the risks from various natural disasters and the peculiar climatic conditions of the region: a cold, long drawn winter and a comparatively hot humid summer. They also demonstrated a profound understanding of locally available construction materials in which wood played a major role.

The soundness of the historic vernacular architecture of Kashmir has also been proven in the series of studies carried in the aftermath of the 2005 earthquake (Jigyasu and Hamdani, 2006). It remains relevant given what is understood about the floods of 2015 (Chawla and Iqbal, 2015) and their effect on various building typologies.
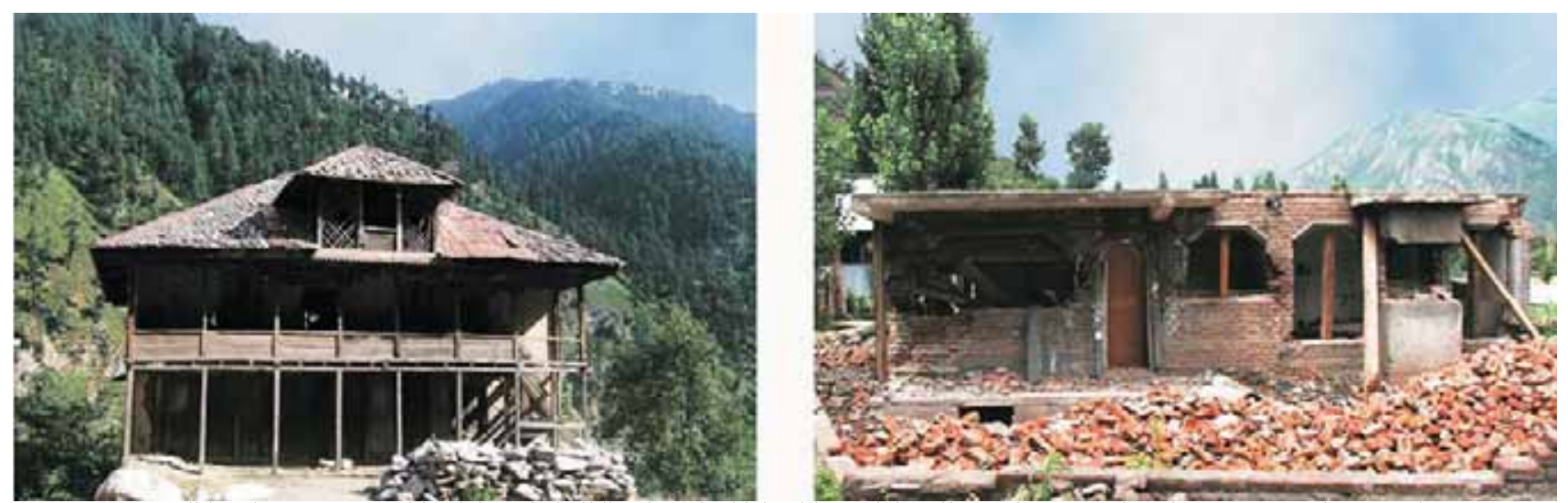

Figure-1: A traditional two storey residential (Left) building in Uri which withstood the effects of 2005 earthquake as compared to a modern cement concrete building (Right).

Source: INTACH J\&K, 2005

* M. Saleem Beg, Member, National Monuments Authority, Former Convener INTACH, J\&K, India. Email correspondence: saleembeg@gmail.com

** This paper was presented at the First Conference on Urban and Regional Planning, organised by the Department of Architecture and Planning, NED University of Engineering and Technology, in March 2017. 


\section{VERNACULAR BUILT HERITAGE OF KASHMIR, DOWN THE AGE}

The vernacular architectural representation of Kashmir is now threatened by the political turmoil, changing socio economic factors and introduction of modern building materials and technologies. Yet from various accounts (Moorcroft and Trebeck, 2000), it seems that the building traditions of the region survived various natural as well as manmade disasters, though there were periods of decay as well, reflecting the prevailing socio-political ills rather than the loss of building skills. This was owing to the fact that the builders understood and accepted the efficacy of these traditional building processes, both in materials and styles, in the face of earthquakes and floods. The vernacular typologies thus were accepted as the appropriate response to these disasters. These typologies evolved during the centuries and were retained in newer constructions for fresh or damaged buildings. The oldest surviving examples of traditional vernacular architecture, mostly in the form of residences in Srinagar date back to the late 19th century (Figure 2). This holds true for other major towns of Kashmir Valley.

\section{THE BUILDING SYSTEMS}

The vernacular architecture of Kashmir is broadly represented by the dwelling units in the city and towns, and falls into two distinct categories based on the structural system involved, the taq and the dhajji dewari systems (Hamdani, 2010) (Figure:3). By the early 20th century, under British influence, a newer load-bearing system slowly started replacing both these traditional construction systems. The new system incorporated the essential elements and features of the traditional technologies and materials.

In the taq system of construction $2 \frac{1}{2}-3 \mathrm{ft}$ thick brick masonry piers supporting wooden floor beams formed the basic structure of the building. The distance between two brick piers normally used to be around 3-4 $\mathrm{ft}$ and was known as a taq. The taq thus formed the basic structural bay of the

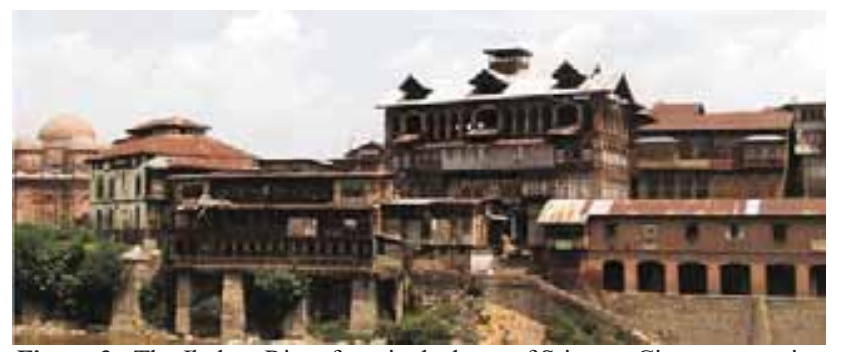

Figure-2: The Jhelum River front in the heart of Srinagar City, representing the architectural legacy of the region.

Source: INTACH J\&K, 2009 building. The gap in between each taq was filled in with a window opening or brick masonry. Normally the inner face of the structure would be made of sun dried brick (kham seer) or rubble infill. The superstructure usually rested on a 3-4 ft high stone plinth constructed in random rubble masonry. A series of twin wooden (deodar) tie beams called das separated the stone masonry from the burnt brick masonry of the superstructure and acted as an isolated diaphragm in between the two layers. In many cases the ground floor was also constructed in random rubble masonry. The superstructure thus behaved as a framed structure, and this accounts for the considerable success that these buildings had in withstanding earthquakes.

An interesting feature of many such buildings was the absence of a truss system supporting the roof. The roof comprised a layer of earth covering over birch bark and wooden planks resting on wooden rafters. The rafters were in turn supported on a wooden log (nar kooth) running along the entire length of the building. Projecting floor joists were used to support bay windows known as $d u b s$. The birch bark mud layered roof was replaced first by wooden shingles and later by zinc coated iron sheets (Figure 3 ).

The dhajji-dewari construction was based on a braced timberframed structural system in which 4-9 inch thick brick masonry was normally used to fill in the gaps left in between these braces. Very few buildings exist today whose construction is entirely based on this system. As in the taq system, the floors were supported on wooden joists (verami). Normally this system was limited to upper floor levels or attics (kani) of the building. This type of construction shows remarkable resilience to earthquakes. As Kashmir is located in the most sensitive earthquake zone, both these systems remained popular (Langenbach, 2009); in fact, they were the only two systems that continued to be followed until the 1950s. When newer materials like cement and steel became widely available, the engineering discipline whose knowledge was restricted to use of these materials replaced both the traditional knowledge and dependence on the locally available building materials.

\section{VERNACULAR HERITAGE IN THE POST- INDEPENDENCE PERIOD}

The Post-Independence period represents a marked shift in the residential architecture of the region. Contemporary residences in the region can be characterized as a hybrid, uniting modern and vernacular, yet they mark a significant break with the traditional vernacular architecture of the region. Designed by engineers and architects, they represent 

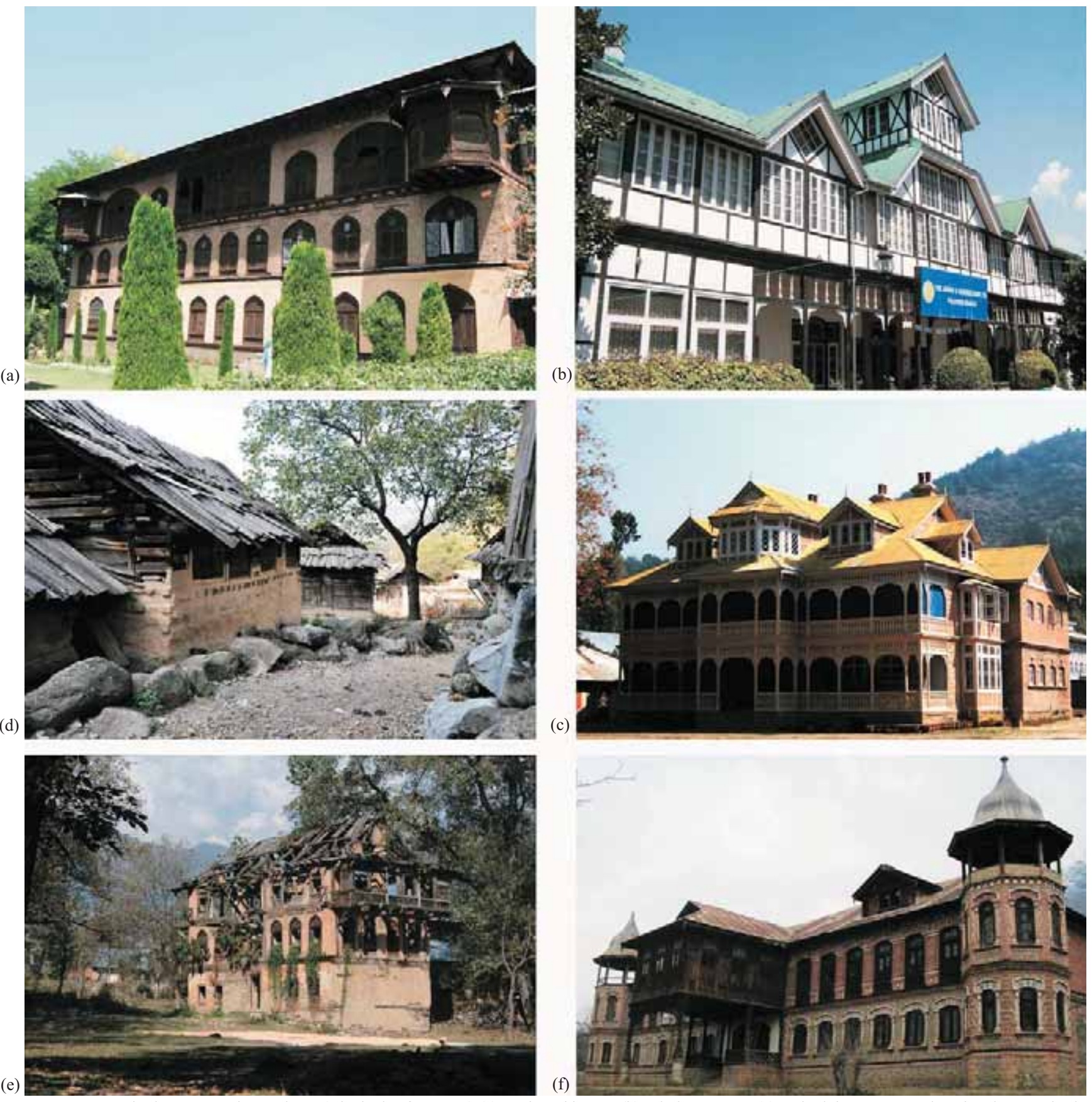

Figure-3: Kashmir's Vernacular Heritage (Clockwise from Top) (a) taq based house, (b) Dhahji Dewari, (c) Colonial House Mansion showing Synthesis of Kashmir and Colonial Influences, (d) abandoned tak based Residence and Wooden log house, Circa. Late $19^{\text {th }}$ to mid $20^{\text {th }}$ Century. Source: INTACH J\&K.

a changing value system in the society, wherein "bigger" and "costlier" have become synonymous with "better". Thus, the mud plastered houses of yesterday are increasingly seen as representing a "poor past": a past that is being torn apart, as old houses, bridges, mosques and shrines make way for new constructions of cement concrete and glass.
Traditionally, the vernacular architecture of the region was characterized by an optimal economical use of space. In fact, these buildings may be regarded as precursors of the modern concept of multi-functional usage of built space. Unfortunately, this feature is no longer found in the modern construction. These vernacular buildings, constructed from 
local materials, also exhibited a great appreciation for human comfort, on how and when the spaces were used. They were warm in winters and cool in summers, responding to the needs of the residents.

These buildings of yesterday were also remarkable for a certain "egalitarian" quality.

What normally differentiated the house of a city merchant from that of a peasant in the village was the size of the building alone or a certain finesse of detailing. Otherwise the nature of both the buildings remained the same, whether it be the material or the technology, the spatial layout or even the overall building appearance. There was a logical understanding of the region, its climate, and the way of living coupled with an economic usage of both space and materials behind the traditional vernacular architecture.

\section{VERNACULAR AND THE CHALLENGES OF "MODERNITY"}

As in other parts of the country, the vernacular built heritage of Kashmir is a part of the living heritage. It encompasses houses that people live in, mohalla mosques and shrines that they worship in, on a daily basis, the year round. It is these very living buildings that have been most impacted by newer buildings. Families grow, houses are divided, and there are additions such as a kitchen, bathroom or an additional bedroom. These additions inevitably impact the historic fabric of these buildings, and may also affect the neighbouring buildings.

The houses that our forefathers lived in just a century back were built in an age and climate where the notion of furniture was an alien idea. Yet today, in our quest to be perceived as "modern", these features, whether a bed, a sofa or a chair, are seen as essential. Accommodating such simple changes related to the life style in historic buildings, at times conflicts with the existing built fabric, especially where the resulting changes lack aesthetic quality or clash with a structure.

Coupled with this indifference for the past is a steady loss of knowledge associated with traditional construction as well as the necessary materials. The fabrication of historical burnt clay bricks of ( 8 "x4"x11/2") (200x100x40mm), locally known as mahrajji bricks, stopped in the mid $20^{\text {th }}$ century, with the widespread introduction of metric brick (230x100x $75 \mathrm{~mm}$ ) (9"x4"x3"). Similarly widespread use of cement mortar and plaster material resulted in the disuse of lime based mortars and plaster. The art of fine mud plaster, zavul boer is also slowly dying out, with increased use of Plaster of Paris (POP) for plastering of wall surfaces in the interiors. Corresponding to these changes is the ever decreasing number of the local skilled labour force in the building industry. While no figure exists, since the 1980s the trend has been for local masons and labourers in the construction industry to be replaced by a work force drawn from outside the State, especially Bihar and Uttar Pradesh. This trend can be explained by a lack of interest in many traditional families of masons and even carpenters to put up with inadequate wages. Additionally, people in the valley perceive non-local skilled and unskilled workers as being more efficient and economical.

Access to regional natural resources is crucial, and the access must be economical from the standpoint of the person with modest resources and must be a sustainable use of those resources. For example, Deodar wood - a central element in Kashmir traditional building - is now expensive, but still available. Wood imported from areas outside the state of Jammu \& Kashmir is increasingly being substituted for Deodar. Some unauthorised interests, active during the political turmoil of the 1990s have caused great damage by large-scale, illegal felling of forest trees. Deodar is perhaps the principal but not the only tree of importance to vernacular architecture. The other trees include kail (pine), budloo (fir) and phrast (poplar). Historically kachil (spruce), bre (jujube) and sometimes even $\mathrm{tul}$ (mulberry) were also employed, though on a smaller scale. All these kinds of timber were used depending on the building element to be fabricated and the money available. In an ideal world, there would be an effective re-afforestation scheme in which deodar was the tree being conserved for future generations. In an ideal world, the available laws would be enforced for the benefit of society and without exception.

But in Kashmir, things are different. Consequently a large part of the vernacular heritage of the region is increasingly morphing into an ugly looking patchwork of the old and the modern. Given the lack of awareness amongst the general public and even in many of the professionals, about how different materials behave and how traditional structures behave, modern additions to old structures also adversely affect their structural integrity.

To save this rich yet fast disappearing architectural legacy of yesterday, it is imperative to document it in typologies, styles and traditional building knowledge systems so that measures can be taken to protect it and make adaptive use of the knowledge behind this architectural style. Nevertheless the choice between where and what a "prospective consumer" may choose, when designing his home or mohalla shrine, 
is always a personal decision, reflecting his or her evaluation and aesthetic sense. Yet by raising awareness about the architecture of yesterday, about the practicalities of its functions, about its environment-friendly components one can at the least hope, that the choice is an informed one.

\section{INITIATIVE FOR PROTECTING KASHMIR'S VERNACULAR HERITAGE}

With this objective in mind some small steps and local initiatives have been taken to preseve the heritage of Kashmir. These initiatives are being received well by the local communities, and also by the professional fraternity of architects, urban planners and the craftsmen.

The first step undertaken in the State to protect and preserve its built heritage was to embark on the documentation of the architectural heritage of the region, especially the fast vanishing vernacular heritage. In all more than 800 vernacular buildings were listed in the capital city of Srinagar alone in 2004. The original listing was compiled in four volumes. An edited version of the report was published in 2010 as a two volume book, Cultural Resource Mapping of Srinagar (Hamdani et. al., 2010). Subsequently the listing program was expanded to other towns of the State of Jammu and Kashmir, with the financial support of the National Mission on Monuments and Antiquities, Government of India. Although this work cannot be termed all-encompassing and exhaustive, yet for the first time an exercise was undertaken to list both the vernacular architecture of the region as well as document various construction practices, spatial layouts and architectural details associated with this architectural genre in Kashmir, as well as in certain areas of the Jammu region.

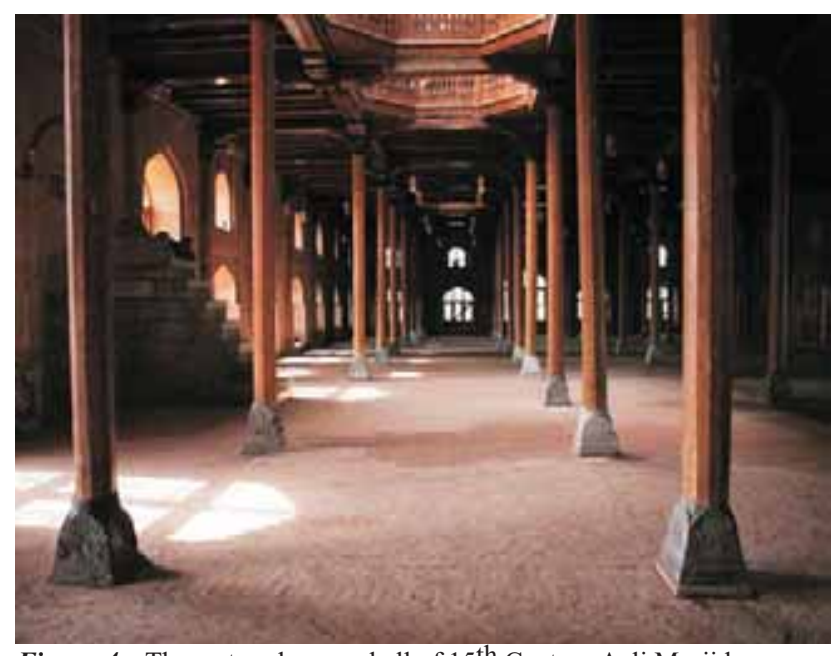

Figure-4: The restored prayer hall of $15^{\text {th }}$ Century Aali Masjid.
The listing process and condition assessment, in addition to providing with a cultural mapping database of the architectural heritage of the region, also lead to identifying projects for conservation in the State. The first such project that was undertaken was the conservation and restoration of the $15^{\text {th }}$ century wooden hypostyle mosque, Aali Masjid at Srinagar (Hamdani and Khan, 2007). The successful completion of projects such as mosque conservation (Figure 4) has resulted in the emergence of a debate within the local community about how to look at the built heritage, especially the living "vernacular" heritage. Acting as exemplars these conservation projects are helping collectively as a society to reappraise the way our forefathers built, and also prompt us to understand the underlying knowledge behind traditional ways of construction.

The listing process was supplemented by digitized documentation of prominent wooden buildings in Kashmir. This extensive exercise proved extremely helpful when the revered $18^{\text {th }}$ century wooden shrine of Dastgeer Saheb at Srinagar was gutted in a devastating fire in June, 2012. It was only on the basis of the detailed documentation of this shrine that had been undertaken by Indian National Trust for Art and Cultural Heritage (INTACH) (Hamdani and Hakak et. al., 2010) that reconstruction of the shrine to its original form could be carried out (Figure 5).

The reconstruction represents a continuation of the various spaces, architectural elements and details at the site as they were designed historically. It also incorporates reworking of some of the traditional construction practices, based on contemporary understanding of materials. All this has been done to ensure an optimal use of building materials such as
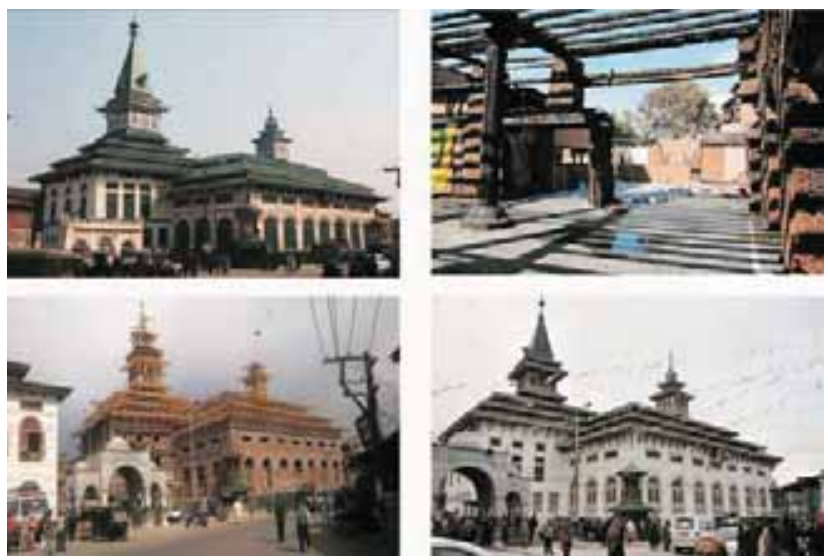

Figure-5: Reconstruction of the historic Dastgeer Saheb Shrine based on prior detailed documentation, (Clockwise from top) the Shrine prior to fire, after fire, the new restored shrine, are shrine during the reconstruction. Source: INTACH, J\&K. 
wood, while retaining the spirit of traditional construction practices (Hamdani and Hakak, 2010a). This project gave the political leadership an opportunity to demonstrate their commitment to the culture and heritage which they emphasize. The community at large also gained a sense that their identity was reaffirmed by this endeavour (Figure 6).

Although listing, documentation and actual conservation works at a site help in raising awareness amongst the community towards the built heritage, it remains a struggle to protect these buildings. The demolition of the $19^{\text {th }}$ century colonial building at Ganpatyar, Srinagar, housing the Lal Ded Memorial School brings this issue to fore. This colonial building which had developed some minor structural cracks was declared unsafe by the Srinagar Municipal Corporation in 2008. In an apparent nexus between some builders and certain officials of the State, the building was demolished. This happened despite the fact that INTACH had provided the state administration with a report, underlining the cultural significance of the building, which had also served as the first office of the Srinagar Municipality. The proposal also included guidelines for retrofitting and strengthening of the building (INTACH and Desai, 2008).

The destruction of heritage buildings such as Lal Ded School highlights the need for an effective legal mechanism for protection the built heritage, as also the need for community mobilization on such issues. Consequently, INTACH, which had been pursuing the issue of lack of legal protection for the built heritage, was able to convince the government for the need to enact the legislation. Finally, the state legislature adopted a bill which became the J\&K Heritage Conservation and Preservation Act, 2010. This statute, which is the first of its kind in India, covers tangible, intangible, man-made and natural heritage and was drafted for INTACH by the legal luminary, the late Shyam Chainani. Nevertheless, the Act has not been implemented very obviously. The conflict situation prevailing in the State for the last twenty five years has taken a heavy toll on civic, urban and social infrastructure and its management.

To interpret the glories of the Dastgeer Saheb, some may find a parallel with Alhambra at Granada, Spain $\left(13^{\text {th }}\right.$ century). That precedes Dastjee Saheb by four centuries, yet in some of the ceilings at Alhambra, especially the wooden ones in the Sala de la Barca and the Throne room, there is similarity of design. The reason is, of course, the

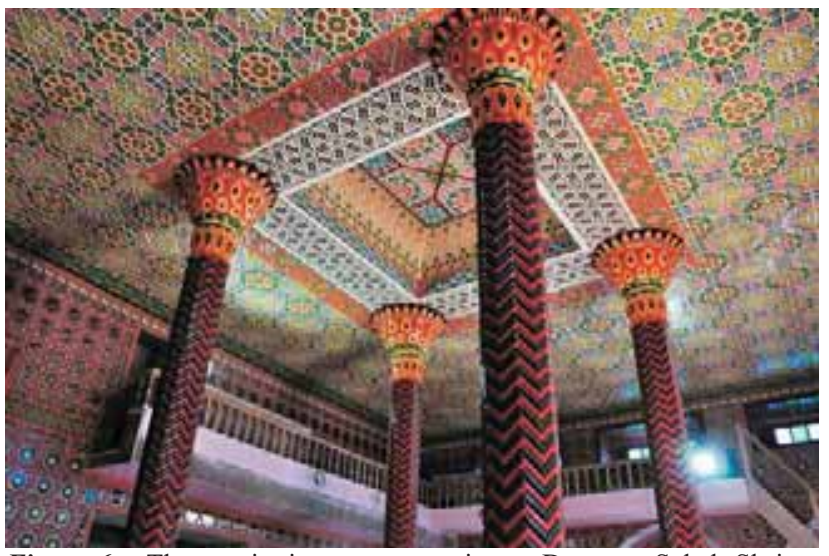

Figure-6: The continuing reconstruction at Dastgeer Saheb Shrine, involving a revival of traditional decorative building crafts like Khatamabandi, papier mache, ornamental woodwork and calligraphy, Inner Main Hall.

Source: INTACH, J\&K, 2014

wide similarity of geometrical motifs employed throughout the Islamic world. Those in Kashmir derive from Persia and Central Asia.

\section{CONCLUSION}

Although considerable progress has been made in the long drawn process of documentation and listing of the vernacular heritage of the region, it is only through live projects that the skill and knowledge behind the traditional building skills can be effectively demonstrated. People learn by doing; and craftsmen and craftswomen need encouragement from the marketplace. On-site training programs for masons, carpenters and engineers during the conservation of historic built fabric are necessary. There is also a need to inculcate the traditional building skills and knowledge in designing contemporary buildings in a creative manner which works as synthesis of old and new. The point is not always repetition of the old, but rather society needs an adaption based on understanding which will lead to integrating the traditional knowledge to the present requirements. The vernacular structures are substantially disaster resistant, economical, environment-friendly, and visually pleasing. It is only when we are able to demonstrate these qualities in the contemporary design and construction that we will be able both to preserve the knowledge of yesterday and also ensure a continuity of a creative process, linking the past to our future. 


\section{REFERENCES}

Chawla,M. and Iqbal,S., 2015, "Damage Assessment Mission in Srinagar City, Kashmir”, INTACH Kashmir in collaboration with Prince Claus Fund,unpublished report.

Hamdani, and Khan, A., 2007, “Conservation of 15th Century Wooden Hypostyle Aali Masjid at Srinagar, Kashmir”, INTACH, J\&K, unpublished report.

Hamdani, S., 2010, "Vernacular Architecture in Shehar-i-Kashmir: Cultural Resource Mapping of Srinagar City”, Vol I, Srinagar: INTACH J\&K).

Hamdani, S., Iqbal, S., Sharma,S., et.al., 2010, Shehar-i-Kashmir, Cultural Resource Mapping of Srinagar City, Delhi: INTACH, J\&K.

Hamdani, S., Khan, A., Hakak, S., et.al., 2010, "Documentation of Twenty Prominent Wooden Shrines, Khanqahs and Mosques of Kashmir", INTACH, J\&K in collaboration with Department of Tourism, Kashmir, unpublished report.

Hamdani, S., Hakak, S., 2010a, "Detailed Project Report for Reconstruction of Peer Dastgeer Saheb Shrine at Kahanyar, Srinagar", INTACH, J\&K, unpublished report.

Jigyasu, R., Hamdani, S., 2006, "Research Report on Disaster Risk Management of Vernacular Heritage in Kashmir", INTACH, J\&K in collaboration with Research Centre for Disaster Mitigation of Urban Cultural Heritage, Ritsumekan University, Rits-DMUCH, Kyoto, Japan, unpublished report.

Langenbach,R., 2009, Don't Tear it Down! Preserving The Earthquake Resistant Vernacular Architecture of Kashmir, New Delhi: UNESCO.

Moorcroft, W. and Trebeck, G., 2000, Travels in India: Himalayan Provinces of Hindustan and the Punjab,in Ladakh and Kashmir, in Peshawar, Kabul, Kunduz and Bokhara from 1819 to 1825, New Delhi: Low Price Edition, first published 1841.

INTACH, Desai, R., 2008, “Proposal for Retrofitting and Reuse of LalDed Memorial School”, INTACH,J\&K, unpublished report

Shah, H., 2002, Tarikh Hassan, vol. I, Translation by Ahmed, S., Srinagar: J\&K Academy of Art, Culture and Languages. 